\title{
Laboratory Practices for Purification of Polysaccharide
}

\author{
Navanita S.K ${ }^{1}$, Umapathi N.G ${ }^{1}$, Ramu Govindan ${ }^{1^{*}}$ \\ Department of Pharmacognosy, JSS College of Pharmacy, JSS Academy of Higher Education \& \\ Research, Ooty, Nilgiris, Tamilnadu, India
}

\section{*Corresponding Author}

Ramu Govindan, Faculty, Department of Pharmacognosy, JSS College of Pharmacy, JSS Academy of Higher Education \& Research, Ooty, Nilgiris, Tamilnadu, India, Email: ramupharmu@jssuni.edu.in

ORCID No: https://orcid.org/0000-0002-0572-9517

\begin{abstract}
The present work aims to purify the mucilage polysaccharide extracted from linseed by deproteinization using Trichloroacetic acid (TCA) and Hydrochloric acid ( $\mathrm{HCl}) .10 \%$ w/v TCA deproteinized more than $80 \%$ when the $\mathrm{pH}$ of the polysaccharide solution was 3 . TCA can be considered as a better deproteinizing agent when compared to hydrochloric acid as evidenced by the highest deproteinization efficiency $(88.57 \%)$.
\end{abstract}

\section{INTRODUCTION}

Nature continuously synthesizes huge amounts of polysaccharides, which serve particularly as structural scaffolds like cellulose in plants and chitin in animals or as storage carbohydrates like starch and glycogen ${ }^{1}$. One important source of polysaccharides is seeds of Linseed, a wellknown and easily available drug in the research laboratory. The present work has focussed on the extraction of Linseed mucilage polysaccharide by using acetone as solvent and purification using trichloroacetic acid in comparison with hydrochloric acid for the precipitation of protein by $\mathrm{pH}$ adjustment. 


\section{METHODS}

A UV absorbance ratio at $\mathrm{A} / 260 / 280$ is used to characterize if the polysaccharide contained proteins and nucleic acids. The total protein content was assayed by the Lowry method using Bovine serum albumin as standard.

\section{PURIFICATION TECHNIQUES}

Linseed was soaked and extracted in distilled water $(300 \mathrm{ml})$ by electrical stirring (Figure 1) for 24 hours and to the filtrate twofold the volume of acetone (4 times the volume of aqueous filtrate) was added for the complete precipitation of crude polysaccharide. Then the aqueous polysaccharide solution was treated with $10 \%(\mathrm{w} / \mathrm{v})$ trichloroacetic acid and hydrochloric acid for adjustment of other $\mathrm{pH}$ values $(3,4$, and 5) separately to remove any adherent protein contaminants and deproteinized.

Fig.1. Polysaccharide extracted from Linseed and its aqueous solutions

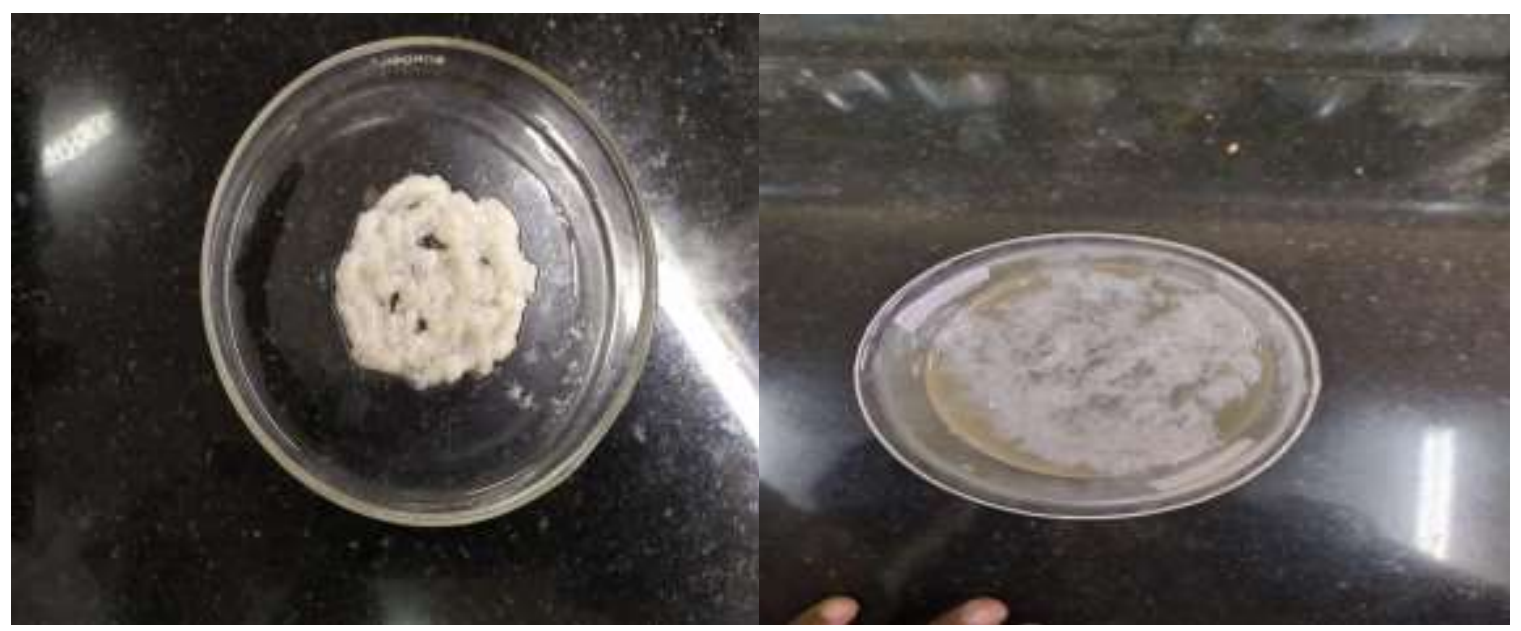



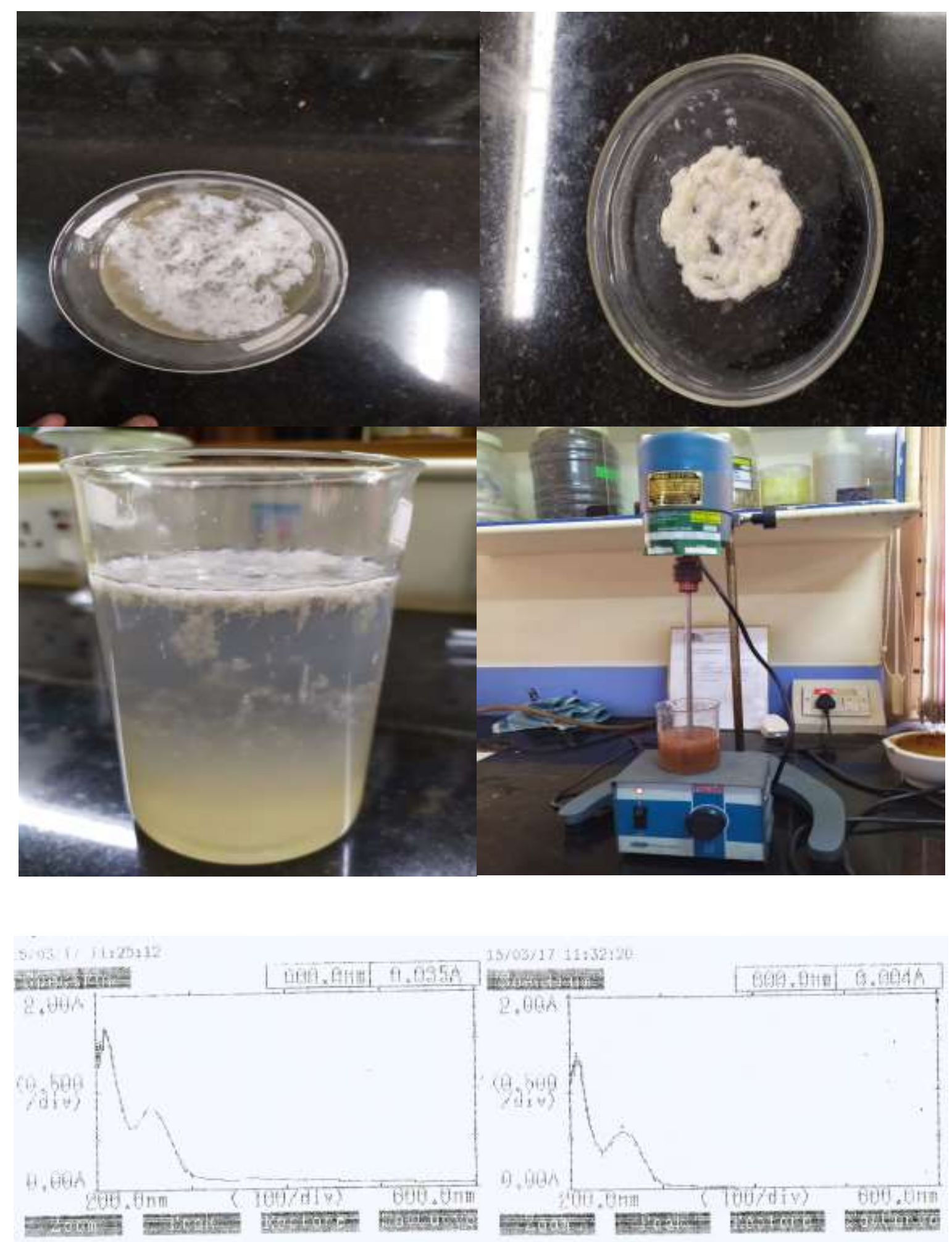

Fig.2 (a \& b). Showing UV spectra of polysaccharide before deproteinization 


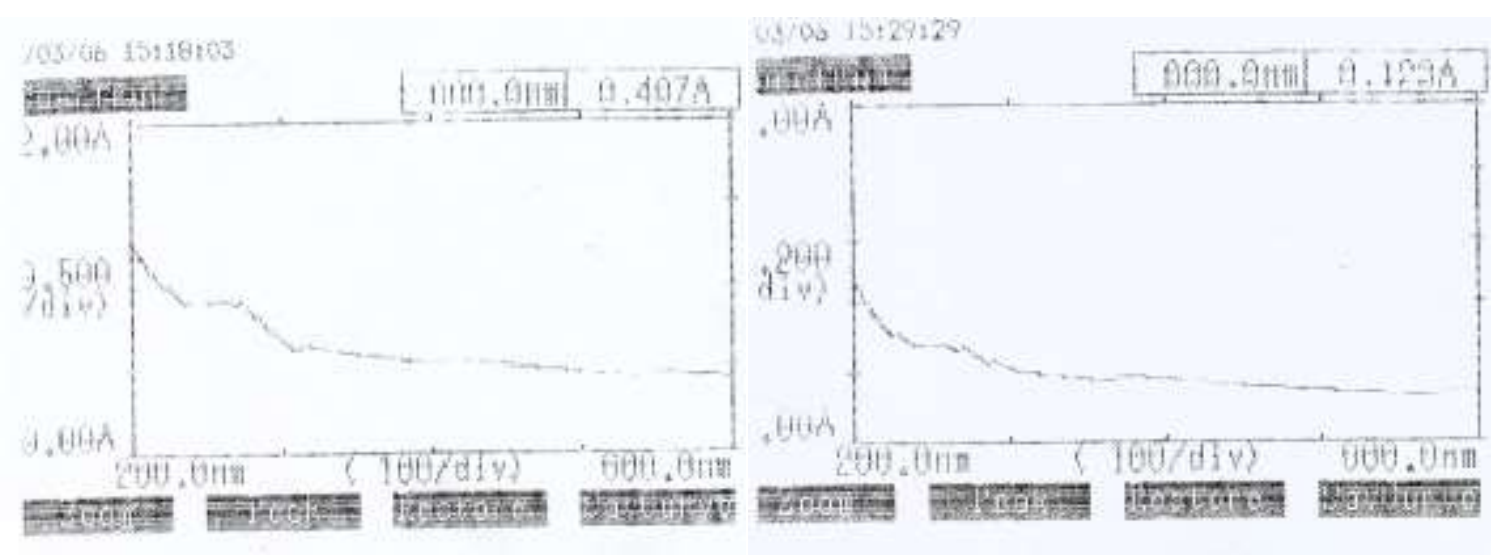

Fig.3 (a \& b).UV spectra of polysaccharide after deproteinization by Hcl \& TCA at pH 3

\section{Determination of protein concentration and deproteinization efficiency}

The concentration of protein was calculated according to the standard calibration curve. The percentage of deproteinization efficiency was calculated by $\mathrm{Co}-\mathrm{Ce} / \mathrm{Co}$ x 100 where $\mathrm{Co}$ and $\mathrm{Ce}$ were the protein concentration before and after deproteinization by trichloroacetic acid and hydrochloric acid respectively.

Table 1. Concentration of protein after treatment with Hcl at different pH

\begin{tabular}{|c|c|c|c|}
\hline S.No. & $\mathbf{p H}$ & Protein $(\boldsymbol{\mu g} / \mathbf{m l})$ & Deproteinization efficiency $(\%)$ \\
\hline 1 & 6.5 & $140(\mathrm{BD})$ & --- \\
\hline 2 & 5 & 120 & 54.28 \\
\hline 3 & 4 & 95 & 72.14 \\
\hline 4 & 3 & 80 & 82.85 \\
\hline
\end{tabular}

$$
\text { BD - Before Deproteinization }
$$

Table 2. Concentration of protein after treatment with TCA at different pH

\begin{tabular}{|c|c|c|c|}
\hline S.No. & $\mathbf{p H}$ & Protein $(\boldsymbol{\mu g} / \mathbf{m l})$ & Deproteinization efficiency (\%) \\
\hline 1 & 6.5 & $140(\mathrm{BD})$ & --- \\
\hline 2 & 5 & 110 & 61.42 \\
\hline 3 & 4 & 87 & 77.85 \\
\hline 4 & 3 & 72 & 88.57 \\
\hline
\end{tabular}

BD - Before Deproteinization 


\section{RESULTS AND DISCUSSION}

Nucleic acids and proteins were detected as indicated by absorption at $260-280 \mathrm{~nm}$ in the UV spectrum. The result obtained is presented in Figure $2(a \& b)$ which shows the UV spectra of Linseed polysaccharide. Before deproteinization, the total protein content of the aqueous polysaccharide solution used in the precipitation assay was $140 \mu \mathrm{g} / \mathrm{ml}$ using BSA as standard.

In the first method of deproteinization, the initial $\mathrm{pH} 6.5$ was decreased by the addition of $\mathrm{HCl}$ to $\mathrm{pH}$ 5. The same procedure was followed for the aqueous extract to other $\mathrm{pH}$ values (4 and 3). After deproteinization, not many nucleic acids and proteins were detected in all the aqueous solutions of different $\mathrm{pH}$ as indicated by less absorption at $260-280 \mathrm{~nm}$ by the effect of hydrochloric acid. Figure 3a. shows the UV spectra of polysaccharide after deproteinization by $\mathrm{HCl}$ at $\mathrm{pH} 3$. The method enabled a reduction of the proteins to $80 \mu \mathrm{g} / \mathrm{ml}$ of the total protein content at $\mathrm{pH}$ 3. The result obtained is presented in table 1 . The deproteinization efficiency was $82.85 \%$.

In the second method, the initial $\mathrm{pH} 6.5$ was decreased by the addition of $10 \% \mathrm{w} / \mathrm{v}$ trichloroacetic acid to other $\mathrm{pH}$ values. The same procedure was followed for the aqueous extract with another $\mathrm{pH}$ value. The result obtained is presented in table 2. Figure $3 \mathrm{~b}$ shows the UV spectra of Linseed polysaccharide after deproteinization by TCA at $\mathrm{pH} 3$. At $10 \% \mathrm{w} / \mathrm{v}$ concentration, trichloroacetic acid proved to be efficient in precipitation of protein reducing to 72 $\mu \mathrm{g} / \mathrm{ml}$ at $\mathrm{pH} 3$. The deproteinization efficiency was $88.57 \%$. TCA can be considered as an better deproteinizing agent when compared to hydrochloric acid as evidenced by the highest deproteinization efficiency $(88.57 \%)$.

\section{ACKNOWLEDGEMENT}

The authors would like to thank JSS College of Pharmacy, JSS Academy of Higher Education \& Research (JSS AHER), Ooty, Nilgiris, Tamilnadu, India for providing the necessary research facilities.

\section{REFERENCES}

1. Kogan G (2000). 1-6 beta D glucan of yeast and fungi and their biological activity. Studies in Natural Products Chemistry, 23, 107-117. 